\title{
Metastasizing adenocarcinoma of the stomach in a harbor porpoise, Phocoena phocoena
}

\author{
Elmar M. Breuer, Barbara H. Krebs, Rainer J. Hofmeister
}

Institut für Veterinär-Pathologie, Freie Universität Berlin, Straße 518, Nr. 15, D-1000 Berlin 37, Federal Republic of Germany

\begin{abstract}
The first case of a metastasizing histologically malignant tumor with fatal outcome in a harbor porpoise Phocoena phocoena is described. According to the World Health Organization (WHO) classification of tumors in domestic animals, this neoplasm represents a well differentiated scirrhous tubular adenocarcinoma of the stomach, metastasizing by way of veins, lymphatics and by implantation in the peritoneal cavity, uterus, lymph nodes, and liver The possible significance of environmental carcinogenic agents being implicated in the induction of this neoplasm - in contrast to fish - can only be suggested in this first case of a malignant tumor in a North Sea harbor porpoise
\end{abstract}

\section{INTRODUCTION}

Over the last few years there has been a significant increase in the number of carefully necropsied marine mammals. However, there have only been a few reports of neoplastic diseases in cetaceans. There is increasing concern that cancer in certain species can be related to environmental pollutants (Geraci et al. 1987). Especially with respect to this possible etiology of neoplasms in marine mammals, it is important to collect and describe systematically all these few available cases. Until now, no case of a malignant tumor in the harbor porpoise Phocoena phocoena has been described. This report is the first documentation of a malignant tumor in this species.

\section{MATERIALS AND METHODS}

During a routine beach survey in September 1988, an adult female harbor porpoise was found dead, beached on the island of Sylt in the Northern Wadden Sea, F. R. Germany. Necropsy tissues were fixed in neutral buffered $10 \%$ formalin, embedded in paraffin, sectioned at about $7 \mu \mathrm{m}$ and stained with hematoxylin and eosin $(\mathrm{H} \& \mathrm{E})$ and with alcian blue.

\section{RESULTS}

The adult animal weighed $75 \pm 5 \mathrm{~kg}$ and measured $178 \mathrm{~cm}$ from lip to posterior flipper. Skin and body orifices were without pathological findings. The thickness of the subcutaneous blubber layer was only $5 \mathrm{~mm}$, measured $10 \mathrm{~cm}$ caudal to the naval. Serous atrophy of the fat depots of the body, especially of the heart and around the kidneys indicated cachexia. Approximately $7 \mathrm{l}$ of a yellowish-grey abdominal fluid and about $700 \mathrm{ml}$ of a clear thoracic fluid were found. The status of tissue preservation was poor, as expected. The fundic compartment of the stomach wall was thickened and transformed into a flattened firm cauliflower-shaped grayish white tumor, measuring $10 \times 10 \times 4 \mathrm{~cm}$. In this area, the tumor penetrated the stomach wall, annularily stenosed the pylorus and infiltrated the surrounding mesenteric tissue. The tumor was accompanied by a severe secondary purulent inflammation. The pancreatic and liver lymph nodes were grossly enlarged and had thickened fibrous capsules. Multiple hazelnut shaped, partly necrotic nodules were spread over all the abdominal organs. The uterine wall was ulcerated and a severe pyohemorrhagic metritis was noted.

Histological examination of the flattened gastric tumor revealed partly columnar formed branched tubular structures and partly cuboidal epithelial cells in a massive fibrous stroma (Fig. 1). In this area the normal mucosa was obliterated and the organoid structured neoplasm infiltrated throughout all layers of the fundic compartment of the stomach wall. The transformed epithelial cells were well polarized, homogeneously eosinophilic, and their nuclei were mostly heterochromatic. Many of the cells contained mucins. Only a 


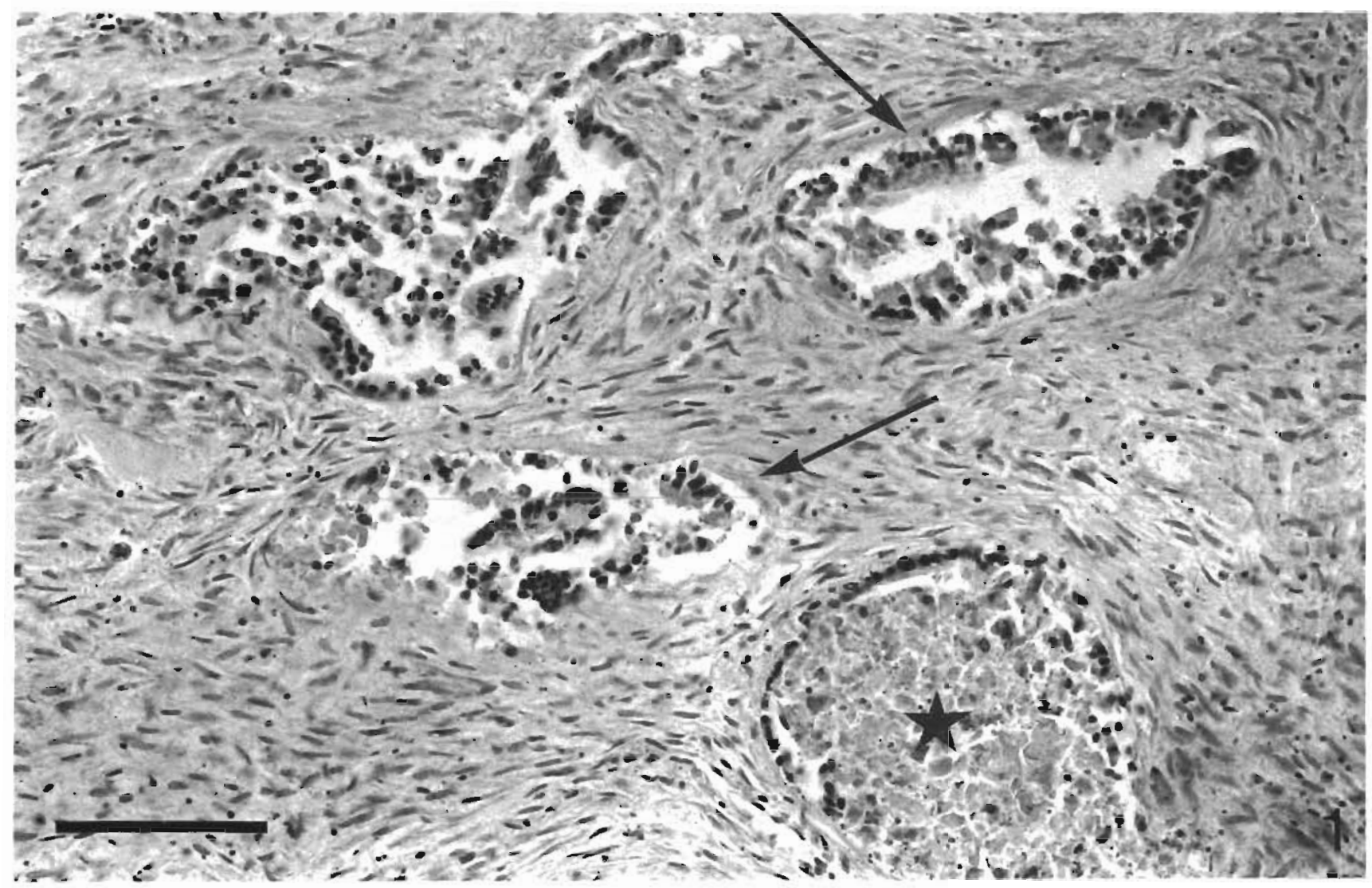

Fig. 1 Phocoena phocoena. Primary site of scirrhous tubular adenocarcinoma in the submucosal layer of stomach wall. Note the massive tumor cell desquamation (arrows) and necrosis (asterisk) in the epithelial palisaded islets. $\mathrm{H} \& \mathrm{E}_{i}$ bar $=100 \mu \mathrm{m}$

few pleomorphic giant cells with euchromatic nuclei were identified. Besides an accompanying reactive non-purulent inflammation there dominated multifocal necrosis surrounded by the peripheral palisading epithelium (asterisk in Fig. 1). The macroscopicallydescribed firm abdominal nodules had the same histological architecture and so could be interpreted as metastasized tumor cells. The myometrium was penetrated by metastasizing tumor cells as well, which provoked a severe ulcerative purulent metritis.

In many sites of the primary neoplasia, as well as in the gastric and hepatic lymph nodes and the mesentery, an excessive lymphangiosis carcinomatosa could be detected, proving a lymphatic-hematological metastatic pathway (Figs. 2 and 3 ). The capsules of 2 of the lymph nodes which were examined were also infiltrated by the neoplasm. Even in the liver, which grossly had no significant lesions, multifocal portal-orientated islands of tumor metastases were found (Fig. 4) compressing the bile ducts. Consequently, a posthepatic icterus was present.

The lower respiratory and intestinal tracts showed no parasites or parasitic alterations other than a few intraalveolar nematodes.

\section{DISCUSSION}

According to the WHO classification of tumors of domestic animals (Head 1976), the neoplasm we have described represents a scirrhous tubular adenocarcinoma, formed typically of branching tubules of columnar, cuboidal, or flattened epithelial cells embedded in a fibrous stroma. The well differentiated col lagenous fibrous tissue may even mask the presence of scattered sparse foci of epithelial tumor cells. The primary site of the tumor is the stomach wall. Implantation of tumor cells in the abdomen results in ascites, because the tumor cells are carried in fluid to the lymphatic drainage sites and then grow in the lymphatic vessels, blocking them and preventing drainage from the abdomen, thus causing ascites (Thomson 1978). A complex lethal neoplastic pathogenesis can be suggested, including loss of function of the lower alimentary system due to stenosis of the pyloric Iumen and partly ulcerative dissiminated metastases. Both pathways led to cachexia. Finally, an obviously secondary severe purulent metritis and an insufficiency of the cardiovascular system led to combined toxinemic and hypoxic lethal shock. 


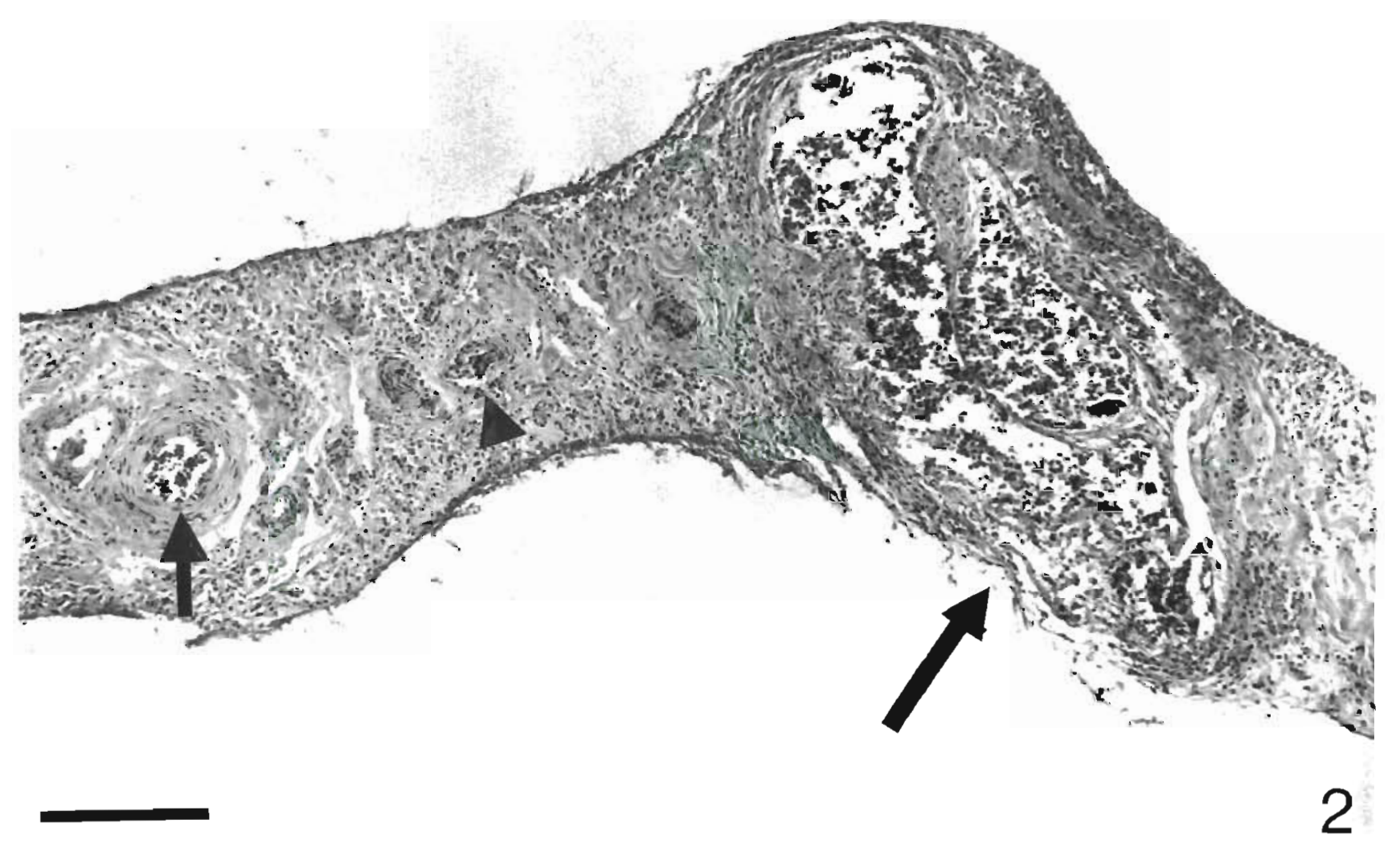

Fig. 2. Phocoena phocoena. Thickened mesentery of small intestıne. Mesenteric tissue is almost completely destroyed by a contact cancer apparently implanted on the lower side (long arrow). Note the combined lymphogenous (arrow head) and hematogenous (short arrow) metastasis and the accompanying inflammation. $H \& E_{;}$bar $=200 \mu \mathrm{m}$

These findings of a metastasizing histologically malignant tumor with fatal outcome in a harbor porpoise have not been reported previously (Cockrill 1960 Sweeney \& Ridgway 1975, Landy 1980, Howard et al. 1983, Dailey 1985, Cowan et al. 1986, Geraci et al. 1987).

Even in man, the knowledge about the complex etio-pathogenesis of the gastric carcinomas is still unsatisfyingly poor (Wanke 1971). In addition to genetic, viral and environmental causes, long-term parasitic alterations of the epithelium have been implicated in the induction of tumors in many species (Wanke 1971, Thomson 1978, Barker \& van Dreumel 1985). In the case which we have described no trace of intestinal parasites could be detected. The discussion remains unresolved if the increasing sea water pollution in the North Sea may produce a decreased resistance in the marine mammals (Breuer et al. 1988, Reijnders 1989) and so could predispose for neoplasia
(Howard et al. 1983). In fish, however, there are reports that environmental carcinogenic substances may induce tumors of many kinds (Pliss \& Khudoley 1975, Matsushima \& Sugimura 1976, Sinnhuber et al. 1977, Couch \& Courtney 1985, Couch \& Harshbarger 1985, Hawkins et al. 1985). Nevertheless, the existing evidence does not permit a firm conclusion (Harshbarger 1977, Mix 1986). Without further epidemiologic studies of a possible upward trend of neoplasia in marine mammals, it seems to be too early to conclude, that there may exist an etiological correlation between water pollutants and neoplastic infestation in harbor porpoises

Acknowledgements. We express our sincere gratitude to Professor Dr R. Rudolph, Institut für Veterinär-Pathologie, Freie Universität Berlin, for his critical review of the paper. We also are very grateful to R. Lick, Institut für Meereskunde an der Universität Kiel and A. Kraus for their kind technical assistance. 


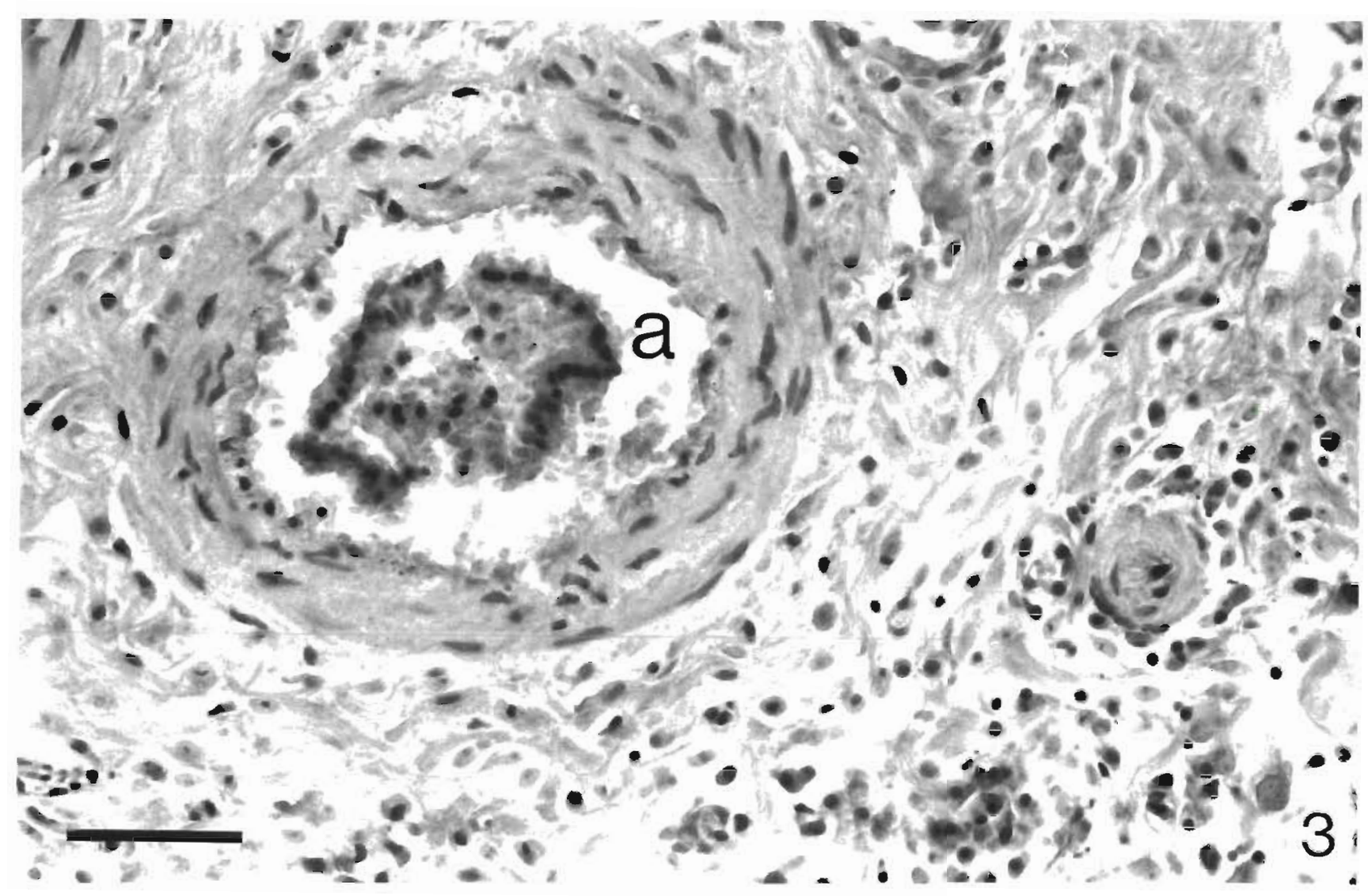

Fig 3 Phocoena phocoena Hematogenous metastasıs in lumen of an arteriole (a) of parametrial tissue. Note the highly purified polarized epithelial tumor cells building tubules with central necrosis $H \& E$, bar $=50 \mu \mathrm{m}$

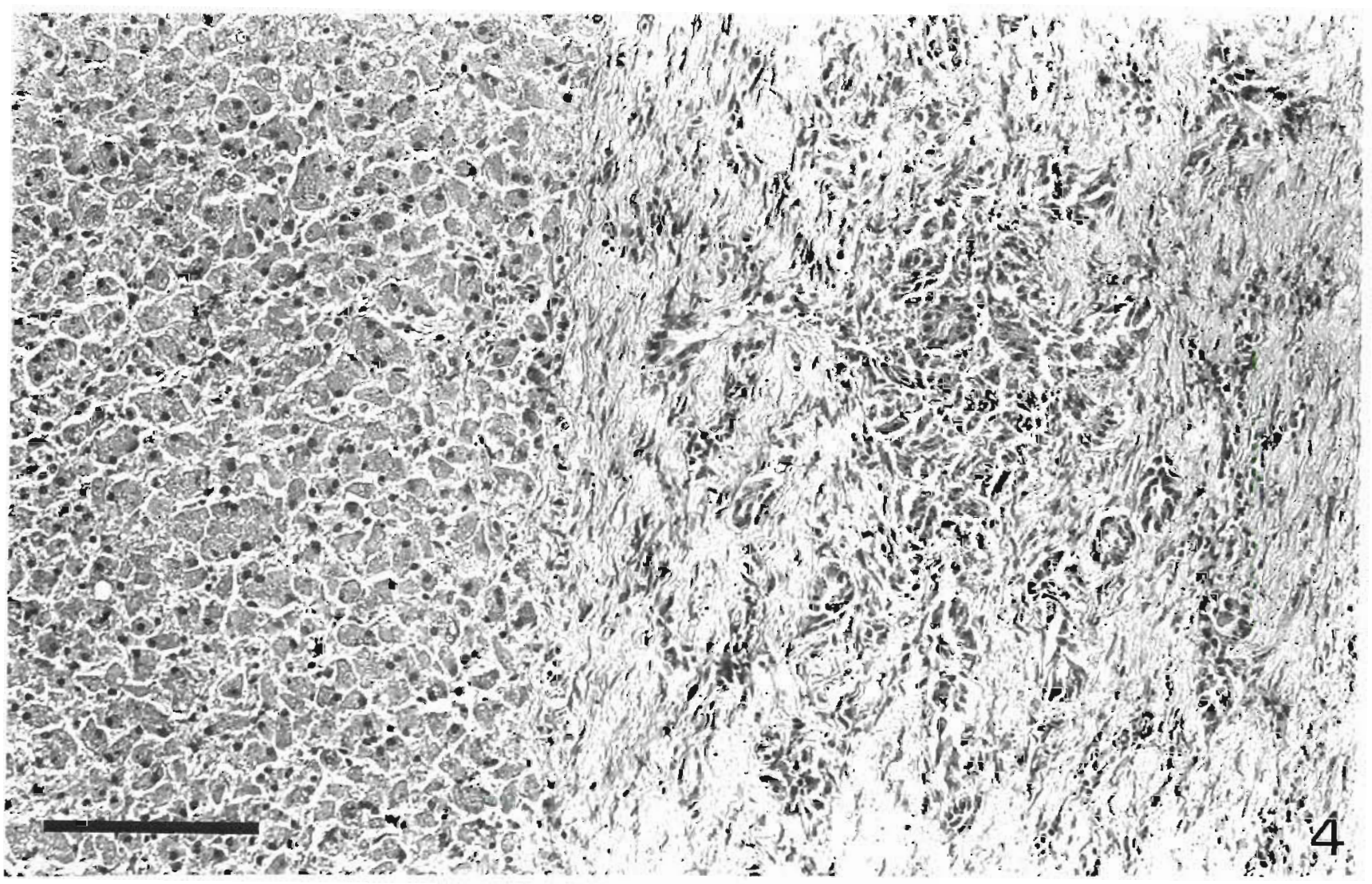

Fig 4 Phocoena phocoena Scirrhous metastasis of tubular adenocarcinoma (right) in high-grade autolvuc liver tissue (left) 


\section{LITERATURE CITED}

Barker, I. K., van Dreumel, A. A. (1985). The alimentary system. In: Jubb, K. V. F., Kennedy, P. C., Palmer, N. (eds.) Pathology of domestic animals, Vol. 2, 3rd edn. Academic Press, Orlando, San Diego, p. 1-237

Breuer, E. M., Ernst, R. H., Hofmeister, R. J., Hentschke, J., Mölle, G., Ludwig, H. (1988). First report of canine distemper-like disease and lesions in harbor seals: pathologic-histologic findings and virus isolation. $Z$. angew. Zool. 75 (2): 129-138

Cockrill, W. R. (1960). Pathology of the cetacea. A veterinary study on whales. Part $1 \mathrm{Br}$. vet. J. 1.16: 133-144

Couch, J. A., Courtney, L. A. (1985). Attempts to abbreviate time to endpoint in fish hepatocarcinogenesis essays. In: Jolly, R. G., Bull, R. J., Davis, W. P., Katz, S., Roberts, M. H., Jacobs, V A. (eds.) Water chlorination: chemistry, impact and health effects, Vol. 5. Lewis Publishers, Chelsea, Michigan, p. 429-438

Couch, J. A., Harshbarger, J. G. (1985). Effects of carcinogenic agents on aquatic animals: an environmental and experimental overview. J. envirl Sci. Illth (Part C Envir. Carcin. Rev.) 3: 63-105

Cowan, D. F., Walker, W. A., Brownell, R. L. (1986). Pathology of small cetaceans stranded along southern California beaches. In: Bryden, M. M. Harrison, R. (eds.) Research on dolphins. Clarendon Press, Oxford, p. 323-367

Dailey, M. D. (1985). Diseases of mammalia: cetacea. In: Kinne, O. (ed.) Disease of marine animals, Vol. IV, Part 2. Introduction reptilia, aves, mammalia. Biologische Anstalt Helgoland, Hamburg, p. 805-847

Geraci, J. R., Palmer, N. C., Aubin, D. J. St. (1987). Tumors in cetaceans: analysis and new findings. Can. J. Fish. aquat. Science 44: 1289-1300

Hawkins, W. E., Overstreet, R. M., Fournie, J. W., Walker, W. W. (1985). Development for aquarium fish models for environmental carcinogenesis: tumor induction in seven fish species. J. appl. Toxic. 5; 261-264

Harshbarger, J. G. (1977). Role of the registry of tumors in

Responsible Subject Editor: Dr M. D. Dailey, Long Beach, California, USA lower animals in the study of environmental carcinogenesis in aquatic animals. Ann. N. Y. Acad. Sci. 298: 280-289

Head, K. W. (1976). Tumours of the lower alimentary tract. Bull. W H. O. 50: 167-186

Howard, E. B., Britt, J. O., Simpson, J. G. (1983). Neoplasms in marine mammals In: Howard, E. B. (ed.) Pathobiology of marine mammal diseases, Vol. II. CRC Press, Boca Raton, Florida, p. 95-162

Landy, R. B. (1980). A review of neoplasia in marine mammals (pinnipedia and cetacea). In: Montali, R. J., Migaki, G (eds) The comparative pathology of 200 animals. Symposia of the Nat. Zoo. Park Ser 6; Smithonian Institution Press, Washington, D.C., p. 579-584

Matsushima, T., Sugimura, T. (1976). Experimental carcinogenesis in small aquarium fishes. Prog. exp. Tumor Res. 20: 367-379

Mix, M. C. (1986). Cancerous diseases in aquatic animals and their association with environmental pollutants: a critical literature review. Mar. enviri Res. 20: 1-141

Pliss, G. B., Khudoley, V. V. (1975). Tumor induction by carcinogenic agents in aquarium fish. $\mathrm{J}$. natl Cancer Inst 55 (1): 129-136

Reijnders, P. J. H. (1989). Seal disease epidemic: epidemical and ecotoxicological aspects in population dynamic contex.t. International Workshop on Current Research in Seal Diseases, Hannover, FRG, February 21-22, 1989

Sinnhuber, R. O., Hendricks, J. D., Wales, J. H., Putnam, G. B. (1977). Neoplasms in rainbow trout, a sensitive animal model for environmental carcinogenesis. Ann. N. Y. Acad. Sci. 298: 389-408

Sweeney, J. C., Ridgway, S. H. (1975). Common diseases of small cetaceans. J. Am. Vet. Med. Ass. 167 (7): 533-540

Thomson, R. G. (1978). General veterinary pathology. Saunders, Philadelphia

Wanke, M. (1971). Magen. In: Doerr, W., Seifert, G., Uehlinger, E. (eds.) Spezielle pathologische Anatomie, Vol. 2, Part 1. Oesophagus, Magen. Springer Verlag, Berlin, Heidelberg, New York, p. 117-1044

Manuscript first received: July 21, 1989

Revised version accepted: September 14, 1989 